NASA/TM-1998-208826

\title{
Impact of Radiation Hardness and Operating Temperatures of Silicon Carbide Electronics on Space Power System Mass
}

Albert J. Juhasz, Roy C. Tew, and Gene E. Schwarze

Lewis Research Center, Cleveland, Ohio 
Since its founding, NASA has been dedicated to the advancement of aeronautics and space science. The NASA Scientific and Technical Information (STI) Program Office plays a key part in helping NASA maintain this important role.

The NASA STI Program Office is operated by Langley Research Center, the Lead Center for NASA's scientific and technical information. The NASA STI Program Office provides access to the NASA STI Database, the largest collection of aeronautical and space science STI in the world. The Program Office is also NASA's institutional mechanism for disseminating the results of its research and development activities. These results are published by NASA in the NASA STI Report Series, which includes the following report types:

- TECHNICAL PUBLICATION. Reports of completed research or a major significant phase of research that present the results of NASA programs and include extensive data or theoretical analysis. Includes compilations of significant scientific and technical data and information deemed to be of continuing reference value. NASA's counterpart of peerreviewed formal professional papers but has less stringent limitations on manuscript length and extent of graphic presentations.

- TECHNICAL MEMORANDUM. Scientific and technical findings that are preliminary or of specialized interest, e.g., quick release reports, working papers, and bibliographies that contain minimal annotation. Does not contain extensive analysis.

- CONTRACTOR REPORT. Scientific and technical findings by NASA-sponsored contractors and grantees.
- CONFERENCE PUBLICATION. Collected papers from scientific and technical conferences, symposia, seminars, or other meetings sponsored or cosponsored by NASA.

- SPECIAL PUBLICATION. Scientific, technical, or historical information from NASA programs, projects, and missions, often concerned with subjects having substantial public interest.

- TECHNICAL TRANSLATION. Englishlanguage translations of foreign scientific and technical material pertinent to NASA's mission.

Specialized services that complement the STI Program Office's diverse offerings include creating custom thesauri, building customized data bases, organizing and publishing research results ... even providing videos.

For more information about the NASA STI Program Office, see the following:

- Access the NASA STI Program Home Page at http://www.sti.nasa.gov

- E-mail your question via the Internet to help@sti.nasa.gov

- Fax your question to the NASA Access Help Desk at (301) 621-0134

- Telephone the NASA Access Help Desk at (301) 621-0390

- Write to:

NASA Access Help Desk

NASA Center for AeroSpace Information 7121 Standard Drive

Hanover, MD 21076 
NASA/TM-1998-208826

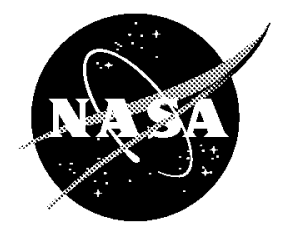

\section{Impact of Radiation Hardness and Operating Temperatures of Silicon Carbide Electronics on Space Power System Mass}

Albert J. Juhasz, Roy C. Tew, and Gene E. Schwarze

Lewis Research Center, Cleveland, Ohio

Prepared for the

Space Technology and Applications International Forum

cosponsored by the Boeing Company, Lockheed Martin, National Aeronautics and Space Administration, U.S. Air Force, and the U.S. Department of Energy

Albuquerque, New Mexico, January 31 - February 4, 1999

National Aeronautics and

Space Administration

Lewis Research Center 


\section{Acknowledgments}

Larry Matus and Philip Neudeck of the NASA-Lewis SiC High Temperature Integrated Electronics and Sensors Team for providing us with information about the development of SiC electronics at NASA-Lewis and elsewhere and encouraging us to do this study

This report is a preprint of a paper intended for presentation at a conference. Because of changes that may be made before formal publication, this preprint is made available with the understanding that it will not be cited or reproduced without the permission of the author.

Available from

NASA Center for Aerospace Information 7121 Standard Drive

Hanover, MD 21076

Price Code: A03
National Technical Information Service 5285 Port Royal Road Springfield, VA 22100 Price Code: A03 
Paper Prepared for

Space Technology \& Applications International Forum

Albuquerque, New Mexico, January 31-February 4, 1999

\title{
Impact of Radiation Hardness and Operating Temperatures of Silicon Carbide Electronics on Space Power System Mass
}

\author{
Albert J. Juhasz ${ }^{1}$, Roy C. Tew ${ }^{2}$, and Gene E. Schwarze ${ }^{3}$ \\ NASA Lewis Research Center, 21000 Brookpark Road, Cleveland, OH 44135-3191 \\ ${ }^{1}$ Mail Stop 301-3, Phone: 216-433-6134,e-mail: Albert.Juhasz@lerc.nasa.gov, FAX: 216-433-6133 \\ ${ }^{2}$ Mail Stop 301-2, Phone: 216-433-8471, e-mail:Roy.Tew@lerc.nasa.gov, FAX: 216-433-6133 \\ ${ }^{3}$ Mail Stop 301-5, Phone: 216-433-6117, e-mail: Gene.Schwarze@lerc.nasa.gov, FAX: 216-433-8311
}

\begin{abstract}
The effect of silicon carbide ( $\mathrm{SiC}$ ) electronics operating temperatures on Power Management and Distribution (PMAD), or Power Conditioning (PC), subsystem radiator size and mass requirements was evaluated for three power output levels $\left(100 \mathrm{~kW}_{\mathrm{e}}, 1 \mathrm{MW}_{\mathrm{e}}\right.$, and $10 \mathrm{MW}_{\mathrm{e}}$ ) for near term technology (i.e., $1500 \mathrm{~K}$ turbine inlet temperature) Closed Cycle Gas Turbine (CCGT) power systems with a High Temperature Gas Reactor (HTGR) heat source. The study was conducted for assumed PC radiator temperatures ranging from 370 to $845 \mathrm{~K}$ and for three scenarios of electrical energy to heat conversion levels which needed to be rejected to space by means of the PC radiator. In addition, during part of the study the radiation hardness of the PC electronics was varied at a fixed separation distance to estimate its effect on the mass of the instrument rated reactor shadow shield. With both the PC radiator and the conical shadow shield representing major components of the overall power system the influence of the above on total power system mass was also determined. As expected, results show that the greatest actual mass savings achieved by the use of SiC electronics occur with high capacity power systems. Moreover, raising the $\mathrm{PC}$ radiator temperature above $600 \mathrm{~K}$ yields only small additional system mass savings. The effect of increased radiation hardness on total system mass is to reduce system mass by virtue of lowering the shield mass.
\end{abstract}

\section{INTRODUCTION}

During the past few years considerable R\&D effort has been devoted to raising the operating temperature limits as well as the radiation hardness (tolerance to neutron fluence and gamma radiation dose) of electronic components (Matus et al., 1997). Significant advances in the use of silicon carbide ( $\mathrm{SiC}$ ) materials for solid state semiconductor components have been especially promising. An expected payoff is that resulting electronic subsystems utilizing such components will be able to operate longer and more reliably, even in a more severe operating environment. For space power systems, high temperature electronics offers additional benefits, namely the reduction of PC radiator size and mass. Moreover, for power systems with nuclear heat sources, increased radiation hardness enables relaxation of shielding requirements for the on-board electronics.

The present study is directed at providing an estimate of just how much system mass savings can be expected from the use of electronic subsystems capable of operation at elevated temperatures and in higher radiation environments. The hypothetical mission for the power system, especially for the $10 \mathrm{MW}_{\mathrm{e}}$ power plant, was assumed to be a precursor cargo spacecraft to Mars with a high specific impulse $\left(\mathrm{I}_{\mathrm{SP}}\right)$ electric propulsion system. Since this power plant was also to provide surface power during the approximately one year Martian stay time, the total mission time of 3 years was assumed for reactor sizing. To perform the study a "Closed Brayton Cycle" (CBC) power system code developed by one of the authors (Juhasz) at the NASA Lewis Research Center was utilized along with a reactor and shield code that was essentially the same as employed by (Dobranich et al. 1987).

To reduce the mass of the high temperature part of the system it was desired to circumvent the need for an intermediate heat exchanger between the reactor and the CCGT. Hence the helium working fluid was assumed to be heated directly in a high temperature epi-thermal pellet bed gas reactor (HTGR), as described in several 
publications at the $10^{\text {th }}$ SSNPS, e.g., (El Genk et al. 1993). Although the above references are to reactors capable of heating the working fluid to near $2000 \mathrm{~K}$, the turbine inlet temperature assumed for this study was a relatively modest $1500 \mathrm{~K}$, thus obviating the need for shield cooling. In agreement with prior system studies for megawatt level power systems (Juhasz et al. 1993) required for inter-planetary nuclear electric propulsion (NEP) applications, an initial system optimization showed that for the power system considered here a nonregenerated power plant would actually result in a lower overall system mass. Hence all system calculations were done for a non-regenerated cycle with the temperature ratio kept constant at a value of 3.1, representing the minimum system mass baseline case.

Regarding the low temperature side of the cycle, the need for a gas-to-liquid heat exchanger was eliminated by ducting the He working fluid from the turbine exhaust section to a heat pipe (HP) main radiator featuring direct forced convection heat transfer from the working fluid to the HP evaporator sections. The cycle reject heat would then be conducted from the HP condensers to carbon-carbon $(\mathrm{C}-\mathrm{C})$ fins and radiator faceplates for eventual heat transfer by radiation to the space environment. The $\mathrm{C}-\mathrm{C}$ composite radiator design was based on development work conducted during the SP-100 program (Rovang et al. 1994) and highlighted in an anniversary publication (Juhasz and Peterson, 1994). This radiator conceptual design has also been proposed for a lunar outpost power system based on the $\mathrm{CBC}$, as well as for the multimegawatt NEP power system referred to above (Juhasz et al. 1993). The PC radiator was also based on the same technology, albeit simpler since it was required to operate at a constant temperature. For this study there was assumed to be no interaction between the PC and main radiators. The sink temperature for the radiators was assumed to be $230 \mathrm{~K}$.

To determine the heat load on the PC radiator three scenarios of electrical energy to heat conversion levels were postulated. These included assumed combined PMAD and payload efficiencies of $0.9,0.5$, and 0.01 , with the highest value representing a power system for which $90 \%$ of the power generated was exported as work energy, while the lowest value implied that practically all the power generated was consumed on-board, being eventually converted into heat. The middle value represented an in between case. It should be noted that heat pump subsystems were not included in this study. Study results for the baseline radiation hardness case for the $10 \mathrm{MW}_{\mathrm{e}}$ system show the effect of electronic operating temperatures on the total system, main radiator, PC radiator and the balance of platform (BOP) mass. The BOP included the reactor and shield, the CCGT turboalternator components, the PC sub-system and the connecting structure. Effects on total system mass, only, are shown for the larger combined PMAD and payload efficiencies. The effect of radiation hardness, in terms of neutron fluence and gamma dose, on shield weight were also studied and results are reported for the baseline PC temperature case.

\section{RESULTS AND DISCUSSION}

First, a study of the effect of electronics temperature on system and PC radiator masses is discussed; for this study the limiting values of neutron fluence $\left(1 \times 10^{13}\right.$ neutrons $\left./ \mathrm{cm}^{2}\right)$ and gamma radiation $\left(5 \times 10^{5} \mathrm{rad}\right)$ used are assumed to correspond to silicon electronics. Then a study of radiation hardness on shield mass is discussed; for this study the PC electronics temperature was held constant at $400 \mathrm{~K}$ ( $127 \mathrm{C})$.

\section{Effect of PC Electronics Temperature on System and PC Radiator Masses}

The temperature of $400 \mathrm{~K}(127 \mathrm{C})$ is approximately equal to the military specification of $125 \mathrm{C}$ which is a current limit that is used for most silicon based electronics applications. It is believed that silicon carbide electronics will be able to eventually operate reliably at $600 \mathrm{C}$ or approximately $875 \mathrm{~K}$, the upper limit used in this study. The information below shows the effect of electronics temperature on system and PC radiator masses. The average PC radiating temperature was assumed to be $30 \mathrm{~K}$ less than the electronics temperature; this is believed to be characteristic of a heat pipe radiator. Results are shown for 10,1 and $0.1 \mathrm{MW}_{\mathrm{e}}$ (megawatt electric) systems.

\section{9\% of Power Rejected through PC Radiator}

The first results shown assume that $99 \%$ of the electrical power generated must be rejected through the PC radiator. This would likely be the case if an insignificant amount of power is rejected via radar, other electromagnetic signals, thermal radiation from the surfaces of the spacecraft, or via direct conversion to work. 
Figure 1 shows how total system mass varies with PMAD and payload electronics temperature for the 10, 1 and $0.1 \mathrm{MW}_{\mathrm{e}}$ power levels; it is

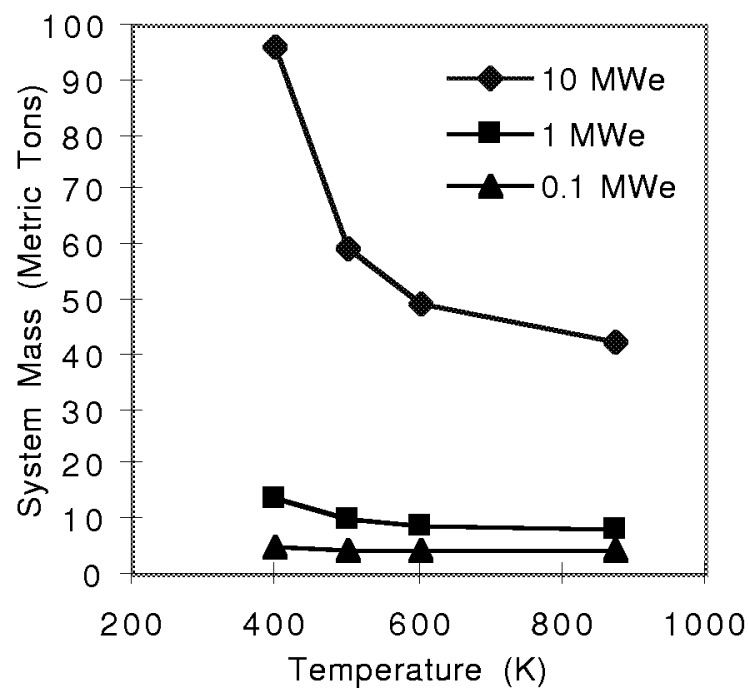

FIGURE 1. System mass as a function of electronics temperature--for $99 \%$ of power radiated via $\mathrm{PC}$ radiator

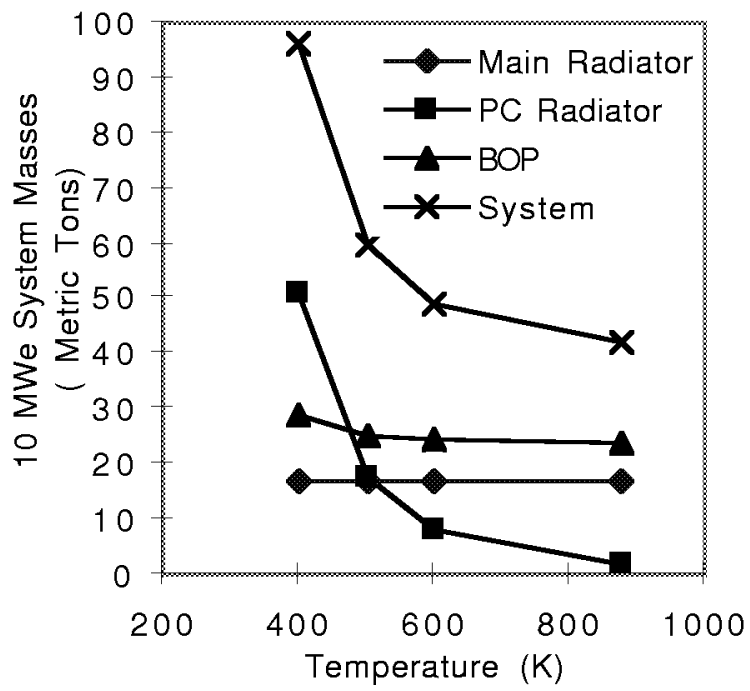

FIGURE 3. $10 \mathrm{MW}_{\mathrm{e}}$ system masses as functions of electronics temperature--for $99 \%$ of power radiated via the $\mathrm{PC}$ radiator.

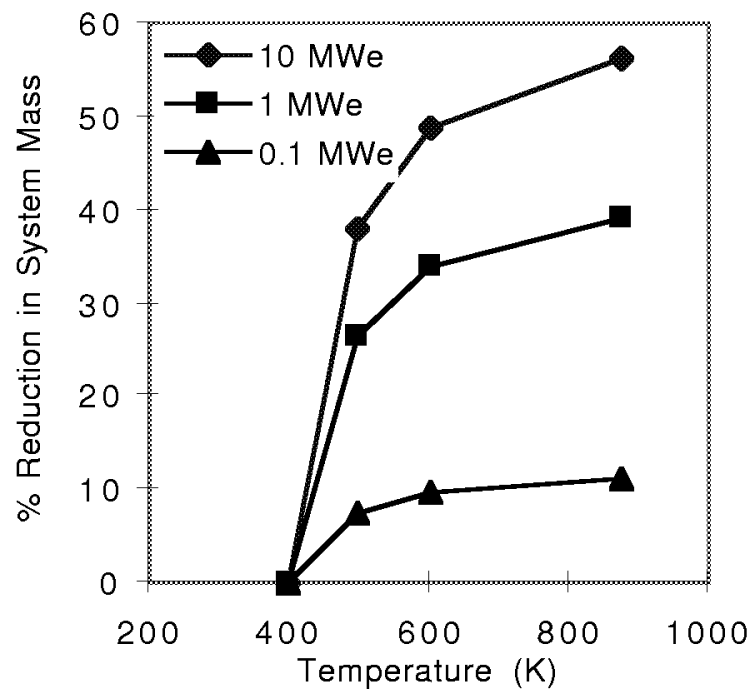

FIGURE 2. Per cent reduction in system mass, relative to that at $400 \mathrm{~K}-$ for $99 \%$ of power radiated via $\mathrm{PC}$ radiator.

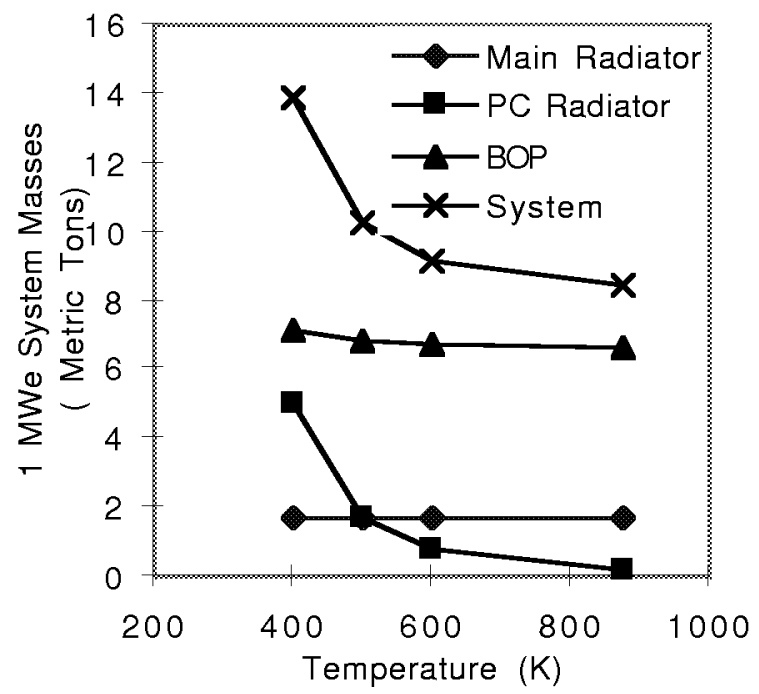

FIGURE 4. $1 \mathrm{MW}_{\mathrm{e}}$ system masses as functions of electronics temperature--for $99 \%$ of power radiated via the $\mathrm{PC}$ radiator.

seen that the larger power systems are more significantly affected by changes in the electronics temperature. Figure 2, based on the same computed data, shows percent reduction of system mass relative to the system mass at $400 \mathrm{~K}$ electronics temperature and provides better resolution for the smaller power systems. The plots also show that most of the potential reduced mass benefit can be achieved by increasing the electronics operating temperature to $600 \mathrm{~K}$ (or $327 \mathrm{C}$ ).

Figures 3, 4, and 5 show system, radiator, and Balance of Platform (BOP) masses for each of the power systems, respectively, as functions of electronics temperature. The BOP mass is the total system mass minus that of the main and PC radiators; it includes the reactor, shield, power conversion system, electronics, and the structural mass. 
For the $10 \mathrm{MW}$ system masses shown in Figure 3, it is seen that at $400 \mathrm{~K}$, the PC radiator dominates the other system components; PC radiator mass becomes less significant if the electronics temperature can be increased. In

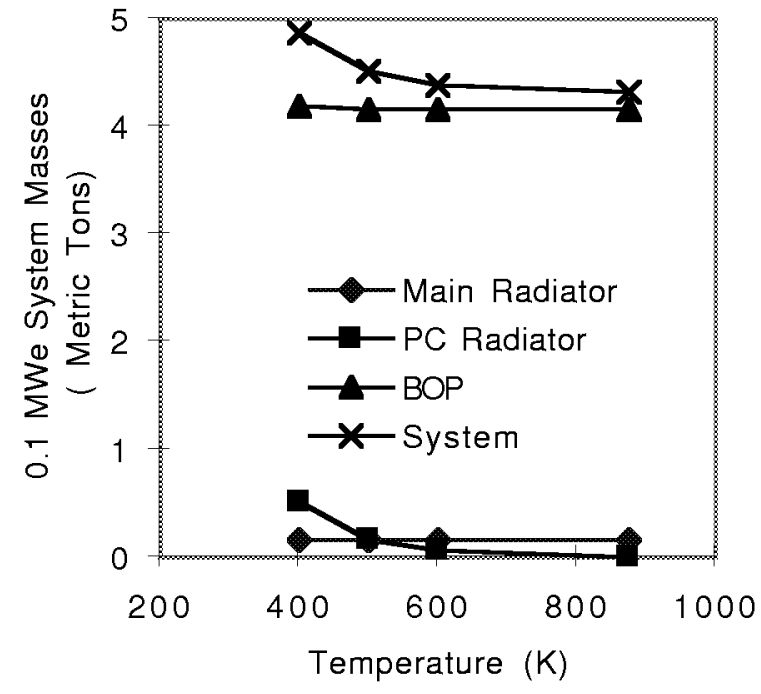

FIGURE 5. $0.1 \mathrm{MW}_{\mathrm{e}}$ system masses as functions of electronics temperature--for $99 \%$ of power radiated via $\mathrm{PC}$ radiator.

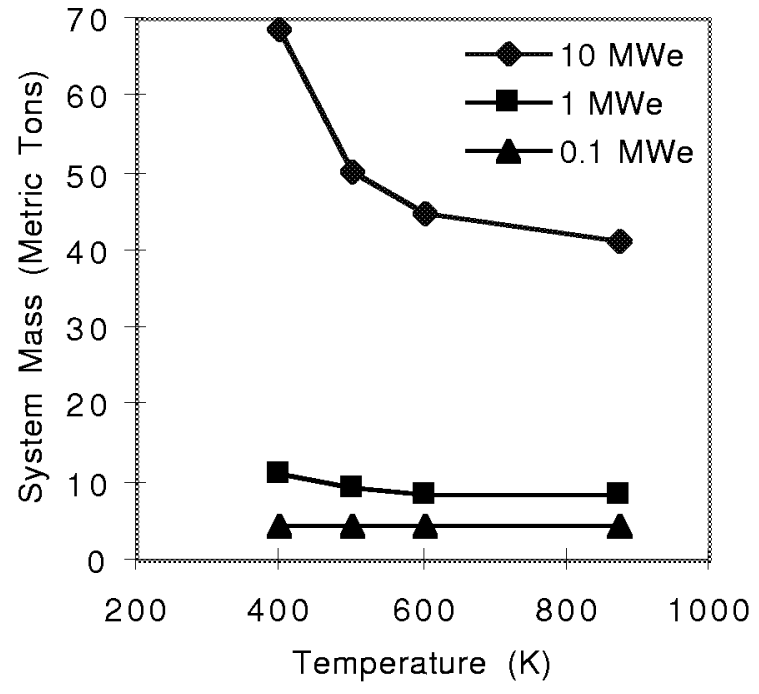

FIGURE 6. System mass as a function of electronics temperature--for $50 \%$ of power radiated via the $\mathrm{PC}$ radiator

comparison, Figures 4 and 5 illustrate that as the power level of the system becomes smaller, and less waste electronics heat needs to be dissipated--the mass of the PC radiator becomes less significant.

\section{$50 \%$ of Power Rejected through PC Radiator}

If $50 \%$ of the electrical power is emitted "directly" from the spacecraft via radar, other electromagnetic radiation or by direct conversion to work, then only the remaining $50 \%$ of the electronics waste heat must be rejected via the PC radiator. For each system power level, reducing PC radiator rejected heat from $99 \%$ to $50 \%$ of the electrical power has the effect, primarily, of reducing the mass of the PC radiator by approximately $50 \%$ and also reduces the structural mass. The effect of increasing the operating temperature of the electronics on the system masses for the 50\% case is shown in Figure 6. Figure 6 shows that for a $10 \mathrm{MW}$ system, increasing the electronics temperature from 400 to $875 \mathrm{~K}$, produces only about half the reduction in system mass $(\sim 27,000 \mathrm{~kg})$ that is shown for the $99 \%$ case of Figure 1 (which shows a reduction of $\sim 54,000 \mathrm{~kg}$ ).

\section{0\% of Power Rejected through PC Radiator}

If $90 \%$ of the electrical power is emitted directly from the spacecraft, leaving only $10 \%$ of the electronics waste heat to be rejected via the PC radiator, the impact on the spacecraft mass of increasing the electronics operating temperature is greatly reduced. This is shown in Figure 7. Here, for a $10 \mathrm{MW}$ system, increasing the electronics temperature from 400 to $875 \mathrm{~K}$ produces a reduction in system mass of less than $5500 \mathrm{~kg}$. This is, of course, because the PC radiator is only a little more than $5100 \mathrm{~kg}$ at the lowest, $400 \mathrm{~K}$, electronics temperature.

The above results show only the effect of increasing the electronics operating temperature on reducing the PC radiator and system masses. Another benefit to be derived by replacing silicon with silicon carbide electronics is increased radiation hardness. Increasing the radiation hardness of the electronics would reduce the mass of the instrument rated shield for a nuclear reactor power system; it would also reduce any requirement to protect spacecraft electronics from other radiation that might be encountered in space. The results shown below address only the impact of electronics radiation hardness on the mass of instrument rated shielding. 


\section{Effect of PC Electronics Radiation Hardness on Shield Mass}

The results discussed here are based on a $46 \mathrm{MW}_{\mathrm{t}}$ (megawatt thermal) reactor heat source for a $10 \mathrm{MW}_{\mathrm{c}}$ CCGT power system designed for three years of operation with a shield having a fixed cone half angle of 15 degrees and $25 \mathrm{~m}$ separation between the reactor and the payload electronics.

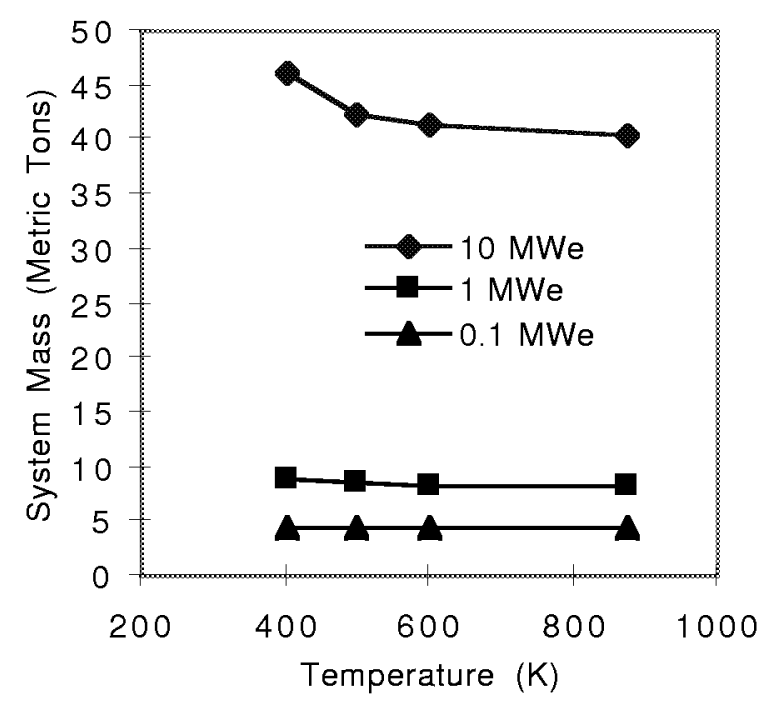

FIGURE 7. System mass as a function of electronics temperature--for $10 \%$ of power radiated via $\mathrm{PC}$ radiator a

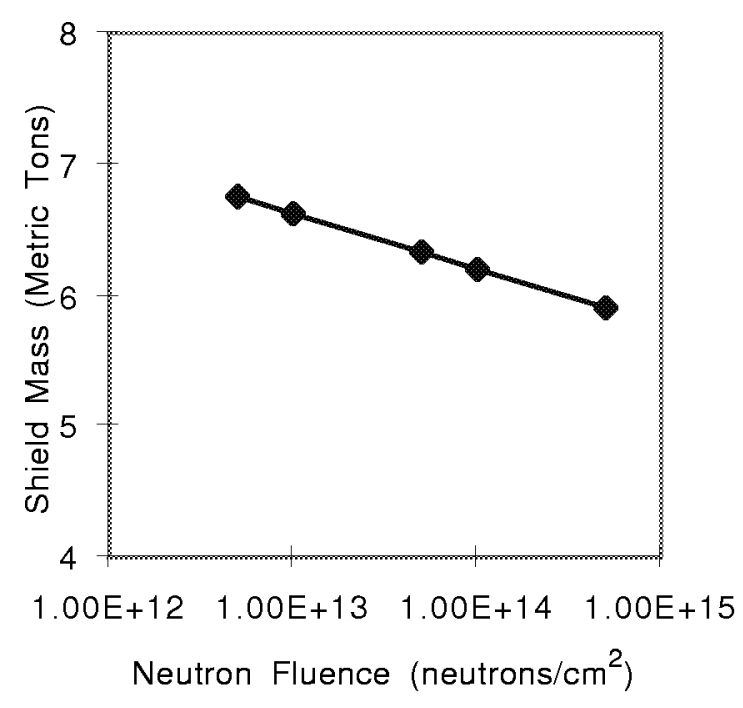

FIGURE 8. Shield Mass as a function of neutron fluence dose limit for a $10 \mathrm{MW}_{\mathrm{e}}$, $\left(46 \mathrm{MW}_{\mathrm{t}}\right) 3$ year system with $25 \mathrm{~m}$ reactor-to-PMAD separation distance.

A neutron fluence of $10^{13}$ neutrons $/ \mathrm{cm}^{2}$ is assumed to be the upper radiation limit of silicon based electronics. A neutron fluence about an order of magnitude larger, i.e., $10^{14}$ neutrons $/ \mathrm{cm}^{2}$, is assumed to be a viable goal for silicon carbide based electronics.

For this study, the neutron fluence was allowed to vary from $5 \times 10^{12}$ neutrons $/ \mathrm{cm}^{2}$ (about one-half the assumed limit for silicon electronics) to $5 \times 10^{14}$ neutrons $/ \mathrm{cm}^{2}$ (about 5 times the assumed limit for silicon carbide electronics). The variation in shield mass (composed of lithium hydride, or $\mathrm{LiH}$, and tungsten, or W, layers for neutron and gamma attenuation, respectively) over this range of limits is shown in Figure 8 as a function of neutron fluence; the gamma radiation dose was held constant at $5 \times 10^{5}$ rad. Increasing the neutron fluence from $10^{13}$ neutrons $/ \mathrm{cm}^{2}$ (upper limit of silicon electronics) to $10^{14}$ neutrons $/ \mathrm{cm}^{2}$ (viable goal for silicon carbide electronics) was found to allow a reduction in shield mass of $435 \mathrm{~kg}$.

The gamma radiation dose was held constant at the silicon electronics limit of $5 \times 10^{5}$ rad for this study because (1) the gamma dose is limited by the gate oxide such as that used in power MOSFETs, and (2) the same oxide is used for both silicon and silicon carbide electronics. If (1) the SiC electronics are limited to semiconductor devices that don't use a gate oxide (such as bipolar junction devices) or (2) a more gamma resistant gate oxide is developed, then it might be possible to increase gamma dose by an order of magnitude, also, from $5 \times 10^{5}$ to $5 \times 10^{6}$ rad. Such an increase, for constant neutron fluence of $10^{13}$ neutrons $/ \mathrm{cm}^{2}$, would reduce the mass of the shield used in this study by $1630 \mathrm{~kg}$. Total shield mass is much more sensitive to gamma dose than to neutron fluence because of the higher mass density of the gamma-tungsten shield as compared to the neutron-LiH shield.

\section{CONCLUDING REMARKS}

Substitution of silicon carbide for silicon electronics would produce substantial reductions in PC radiator and system masses for space power systems of $0.1 \mathrm{MW}(100 \mathrm{~kW})$ and larger--when most of the electronics waste heat must be rejected through the $\mathrm{PC}$ radiator. When $99 \%$ of the electronics waste heat must be rejected through the PC radiator, substitution of $875 \mathrm{~K}(\sim 600 \mathrm{C})$ silicon carbide electronics for $400 \mathrm{~K}(\sim 125 \mathrm{C})$ silicon electronics, was found to produce reductions in system mass of $56 \%, 39 \%$ and $11 \%$ for $10 \mathrm{MW}, 1 \mathrm{MW}$ and 
$0.1 \mathrm{MW}$ power systems, respectively. These percentage reductions in system mass correspond to absolute system mass reductions of approximately 54000,5400 and $540 \mathrm{~kg}$, respectively. These system mass reductions are almost entirely due to reductions in the size of the PC radiator (there is some reduction in structural mass). When these percentage reductions in system mass were plotted as a function of system power level on a semi$\log$ plot and extrapolated to $0.01 \mathrm{MW}(10 \mathrm{~kW})$ and $0.001 \mathrm{MW}(1 \mathrm{~kW})$, it seemed clear that the substitution of silicon carbide for silicon electronics would have negligible impact on the PC radiator and system masses for $10 \mathrm{~kW}$ and smaller power systems.

If the percentage of electrical power rejected through the PC radiator is reduced from 99 to $50 \%$, then the percentage reduction in system masses fall to $40 \%, 25 \%$ and $6 \%$ for 10,1 , and 0.1 MW systems, respectively. A further reduction in the percentage of power lost via the PC radiator to $10 \%$ means that the substitution of $875 \mathrm{~K}$ capable silicon carbide electronics for $400 \mathrm{~K}$ capable silicon electronics would produce reductions in system mass of only $12 \%, 6 \%$, and $1 \%$ for 10,1 , and 0.1 MW systems, respectively.

Suppose that silicon carbide electronics has developed to the point of being capable of operation at "only" $600 \mathrm{~K}(\sim 325 \mathrm{C})$ instead of $875 \mathrm{~K}(\sim 600 \mathrm{C})$. When $99 \%$ of the electrical power is rejected via the PC radiator, substitution of $600 \mathrm{~K}$ capable silicon carbide electronics for $400 \mathrm{~K}$ capable silicon electronics would produce reductions in system mass of $49 \%, 34 \%$ and $10 \%$ for 10,1 , and 0.1 MW systems, respectively. This is not much less than the $56 \%, 39 \%$ and $11 \%$ reductions that could be achieved by substitution of $875 \mathrm{~K}$ capable silicon carbide for silicon electronics. A similar study reported by (Dobranich, 1987) assumed substitution of $600 \mathrm{~K}$ capable for $400 \mathrm{~K}$ capable electronics and a system designed for one year of operation, instead of the three years assumed for this study. Dobranich's study showed reductions of $40 \%, 17 \%$ and $7 \%$ in system mass for 10,1 and $0.1 \mathrm{MW}$ systems. Only the $17 \%$ reduction reported for the $1 \mathrm{MW}$ system seems somewhat inconsistent with the results found in the current study.

The radiation hardness study showed that substitution of $\mathrm{SiC}$ for silicon electronics, with an increase in neutron fluence from $10^{13}$ to $10^{14}$ neutrons $/ \mathrm{cm}^{2}$, would reduce instrument rated shield mass by $435 \mathrm{~kg}$ for a $10 \mathrm{MW}$ system (for constant gamma dose of $5 \times 10^{5} \mathrm{rad}$ ). If the gamma dose could also be increased an order of magnitude, this would reduce shield mass by $1630 \mathrm{~kg}$ (for constant neutron fluence of $10^{13}$ neutrons $/ \mathrm{cm}^{2}$ ). These benefits can be compared with system mass reductions that were found by substituting $600 \mathrm{~K}$ capable $\mathrm{SiC}$ electronics for $400 \mathrm{~K}$ silicon electronics. Such a substitution produced a $47100 \mathrm{~kg}$ reduction in system mass when $99 \%$ of the power is rejected through the PC radiator; the reduction in system mass was about half as large when only $50 \%$ of the power was rejected through the PC radiator.

\section{REFERENCES}

Dobranich, D. "The Effect of Maximum-Allowable Payload Temperature on the Mass of a Multimegawatt Space-Based Platform," Sandia National Laboratory Report \# SAND87-1449, 1987.

El-Genk, M. S.; Morley, N. J.; and Juhasz, A. J. "Pellet Bed Reactor Concept for Nuclear Electric Propulsion," $10^{\text {th }}$ Symposium on Space Nuclear Power and Propulsion, Albuquerque, New Mexico, January 10-14, 1993.

Juhasz, A. J.; El-Genk, M. S.; and Harper, W. B. "Closed Brayton Cycle Power System with a High Temperature Pellet Bed Reactor Heat Source for Nuclear-Electric Propulsion (NEP) Applications," NASA TM-105933, Oct. 1992. (10 ${ }^{\text {th }}$ Symposium on Space Nuclear Power and Propulsion, Albuquerque, New Mexico, January 10-14, 1993).

Juhasz, A. J. and Bloomfield, H. S. "Development of Lightweight radiators for Lunar Based Power Systems," NASA TM-106604. (24 $4^{\text {th }}$ International Conference on Environmental Systems), Friedrichshafen, Germany, June 20-23, 1994.

Juhasz, A. J. and Peterson, G.P. "Review of Advanced Radiator Technologies for Spacecraft Power systems and Space Thermal Control," NASA TM-4555, June 1994.

Juhasz, A. J. and Rovang, R.D. "Composite Heat Pipe Development Status: Development of Lightweight Prototype Carbon-Carbon Heat Pipe with Integral Fins and Metal Foil Liner," NASA TM-106909, May, 1995.

Matus, L.G., Beheim, G.M., Kuczmarski, M.A., Larkin, D.J., Neudeck, P.G. and Powell, J.A.; "Silicon Carbide High Temperature Integrated Electronics," Paper 52 HITEMP Review 1997, April 30, 1997.

Rovang, R.D., Hunt, M. E., and Juhasz, A. J. "Testing of a Liquid Metal Carbon - Carbon Heat Pipe," $11^{\text {th }}$ Symposium on Space Nuclear Power and Propulsion, Albuquerque, New Mexico, January 10-14, 1994. 
\begin{tabular}{|l|c|c|}
\hline 1. AGENCY USE ONLY (Leave blank) & $\begin{array}{c}\text { 2. REPORT DATE } \\
\text { December } 1998\end{array}$ & $\begin{array}{r}\text { 3. REPORT TYPE AND DATES COVERED } \\
\text { Technical Memorandum }\end{array}$ \\
\hline
\end{tabular}

\section{TITLE AND SUBTITLE}

Impact of Radiation Hardness and Operating Temperatures of Silicon Carbide Electronics on Space Power System Mass

6. AUTHOR(S)

\section{FUNDING NUMBERS}

WU-632-1A-1G-00

Albert J. Juhasz, Roy C. Tew, and Gene E. Schwarze

7. PERFORMING ORGANIZATION NAME(S) AND ADDRESS(ES)

National Aeronautics and Space Administration

Lewis Research Center

Cleveland, Ohio 44135-3191

8. PERFORMING ORGANIZATION

REPORT NUMBER

E-11453

9. SPONSORING/MONITORING AGENCY NAME(S) AND ADDRESS(ES)

National Aeronautics and Space Administration

Washington, DC 20546-0001

10. SPONSORING/MONITORING

AGENCY REPORT NUMBER

NASA TM-1998-208826

11. SUPPLEMENTARY NOTES

Prepared for the Space Technology and Applications International Forum cosponsored by the Boeing Company, Lockheed Martin, National Aeronautics and Space Administration, U.S. Air Force, and the U.S. Department of Energy, Albuquerque, New Mexico, January 31 - February 4, 1999. Responsible person, Albert J. Juhasz, organization code 5440, (216) 433-6134.

12a. DISTRIBUTION/AVAILABILITY STATEMENT 12b. DISTRIBUTION CODE

Unclassified - Unlimited

Subject Categories: 20, 27, 33, and 93

Distribution: Nonstandard

This publication is available from the NASA Center for AeroSpace Information, (301) 621-0390.

13. ABSTRACT (Maximum 200 words)

The effect of silicon carbide ( $\mathrm{SiC}$ ) electronics operating temperatures on Power Management and Distribution (PMAD), or Power Conditioning (PC), subsystem radiator size and mass requirements was evaluated for three power output levels $\left(100 \mathrm{~kW}_{\mathrm{e}}, 1 \mathrm{MW}_{\mathrm{e}}\right.$, and $10 \mathrm{MW}_{\mathrm{e}}$ ) for near term technology ( i.e. $1500 \mathrm{~K}$ turbine inlet temperature) Closed Cycle Gas Turbine (CCGT) power systems with a High Temperature Gas Reactor (HTGR) heat source. The study was conducted for assumed PC radiator temperatures ranging from 370 to $845 \mathrm{~K}$ and for three scenarios of electrical energy to heat conversion levels which needed to be rejected to space by means of the PC radiator. In addition, during part of the study the radiation hardness of the PC electronics was varied at a fixed separation distance to estimate its effect on the mass of the instrument rated reactor shadow shield. With both the PC radiator and the conical shadow shield representing major components of the overall power system the influence of the above on total power system mass was also determined. As expected, results show that the greatest actual mass savings achieved by the use of $\mathrm{SiC}$ electronics occur with high capacity power systems. Moreover, raising the PC radiator temperature above $600 \mathrm{~K}$ yields only small additional system mass savings. The effect of increased radiation hardness on total system mass is to reduce system mass by virtue of lowering the shield mass.

14. SUBJECT TERMS

Silicon carbide; Space power systems

17. SECURITY CLASSIFICATION OF REPORT

Unclassified

\section{SECURITY CLASSIFICATION OF THIS PAGE \\ Unclassified}

19. SECURITY CLASSIFICATION OF ABSTRACT

Unclassified
15. NUMBER OF PAGES 12

16. PRICE CODE $\mathrm{A} 03$ 20. LIMITATION OF ABSTRACT

Standard Form 298 (Rev. 2-89) Prescribed by ANSI Std. Z39-18 298-102 